九州大学学術情報リポジトリ

Kyushu University Institutional Repository

\title{
NOTES ON A SPIDER, TETRAGNATHA LAQUEATA L. KOCH, 1871 OF THE BONIN ISLANDS, JAPAN (ARANEAE : TETRAGNATHIDAE)
}

Okuma, Chiyoko

https://doi.org/10.5109/2403

出版情報: ESAKIA. 15，pp.75-78，1980-10-31. Entomological Laboratory，Faculty of Agriculture， Kyushu University

バージョン：

権利関係 : 


\title{
NOTES ON A SPIDER, TETRAGNATHA LAQUEATA L. KOCH, 1871 OF THE BONIN ISLANDS, JAPAN (ARANEAE : TETRAGNATHIDAE)*
}

\author{
CHIYOKO O KUM A \\ Entomological Laboratory, Faculty of Agriculture \\ Kyushu University, Fukuoka 812, Japan
}

\begin{abstract}
Taxonomic and biological notes on a remarkable spider, Tetragnatha Iaqueata L.

Koch, 1871, which is known from three islands in the Pacific, are made.
\end{abstract}

Recently, Tetragnatha Zaqueata L. Koch is discovered from the Bonin Is., Japan (Yaginuma, 1979). This species was described from Upolu in Western Samoa for the first time, and has been recorded only from Samoa and Society Is. It is very interesting to find it from the Bonin Is. in view of zoogeography.

In January, 1980, I made a trip to the Bonin Islands and was able to observe the habits of this spider on these islands. Because of nature conservation, only two paired specimens were allowed to collect. In this paper, additional taxonomic notes as well as biological observations of this spider are given.

I wish to express my sincere gratitude to Professor Y. Hirashima and Associate Professor K. Morimoto of Kyushu University and Professor T. Yaginuma of Ohtemon-Gakuin University for offering invaluable advice. I am also much indebted to Mr. T. Nagashima, who is one of the persons who contributed toward the discovery of this spider on the islands, and many gentlemen for their kind help to my collecting trip to the Bonin Islands. Mr. Nobutoyo Kôda kindly took the photographs of the spider for me.

\section{Tetragnatha laqueata L. Koch 1871}

\section{Figs. (1-11)}

Tetragnatha Iaqueata Koch, L., 1871, Die Arachniden Australiens, 1: 190; Simon, E. 1894, Hist. Naturelle des Araignées, 1(3) : 720; Berland, L., 1929, Araign., in : Insects of Samoa, 8(2): 61 ; Marples, B. J., 1955, Journ. Zool. Linn. Soc. London, 42: 479; Marples, B. J., 1957, Pacif. Sci., 9: 392 ; Yaginuma, T., 1979, Nat. and Anim., 9(8): 35.

Superficially similar to Japanese T. squamata Karsch and T.yesoensis Saito,

\footnotetext{
* Contribution from the Entomological Laboratory, Faculty of Agriculture, Kyushu University, Fukuoka (Ser. 3, No. 78).
} 

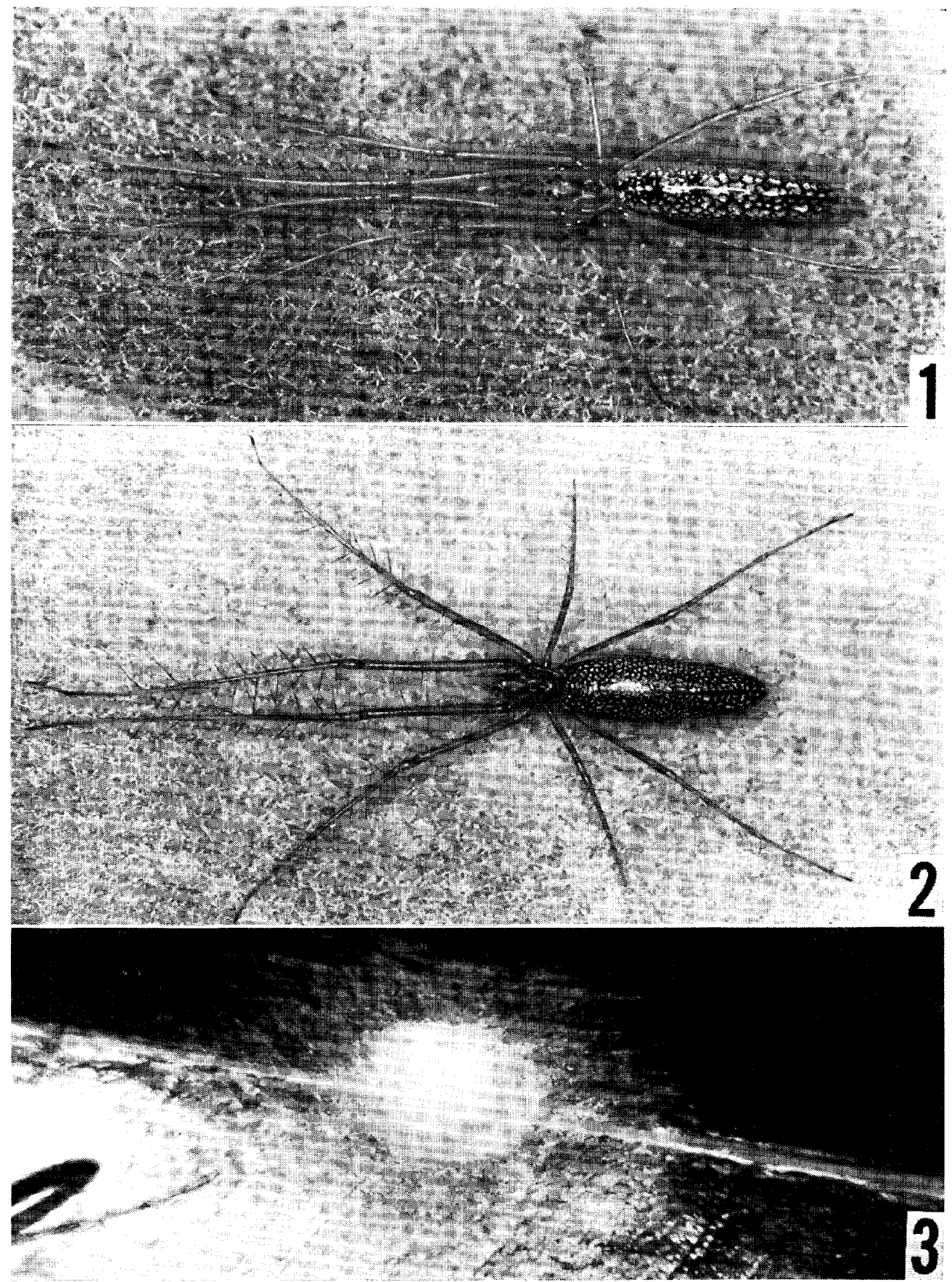

Figs. 1-3. Tetragnatha laqueata L, Koch. 1: Male, 2: Female, 3: Egg-sac, 


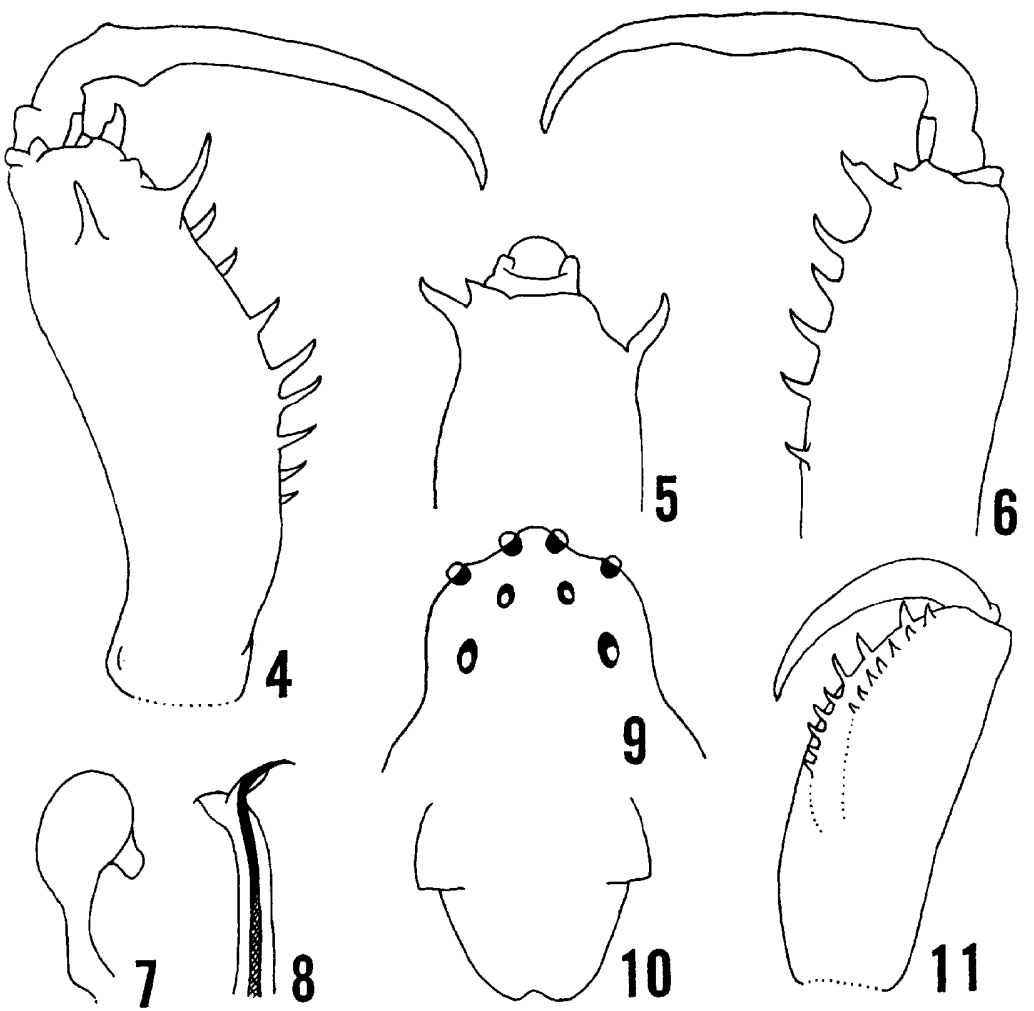

Figs. 4-11. Tetragnatha Eaqueata L. Koch. 4-6: Left chelicerae of male. 7 : Male paracymbium, 8: Distal end of male conductor and embolus. 9: Eye group of female from above. 10: Genital fold of female. 11: Left chelicerae of female.

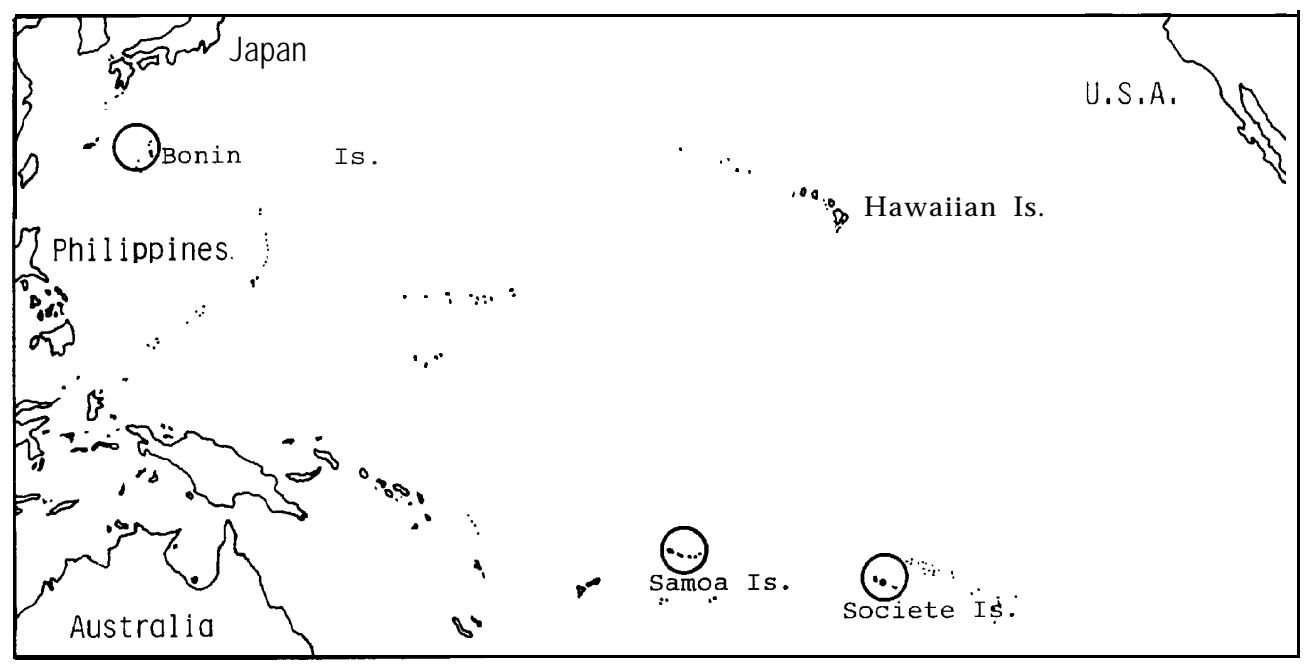

Fig. 12. Distribution of Tetragnatha laqueata L. Koch. 
which are very distinct in their egg-sac forming habit as described below.

Lateral eyes of each side are widely separated; viewed from above, anterior row of eyes gently recurved, posterior row strongly recurved.

Femora, tibiae and metatarsi of the first two pairs of legs armed with two series of long spines regularly spaced, and posterior two pairs are also armed with somewhat weak and a few long spines.

In life, the male is almost yellowish green and with many brilliant yellowish green spangles on the abdomen; the female is somewhat darker and with many brilliant light green spangles on the abdomen.

This spider was collected by beating from the broadleaves of trees in the forest especially in the interior of the island. The spiders were seen clinging to underside of a broadleaf in the daytime. Perhaps, the spider will make a small web at night.

In regard to the egg-sac forming habit, I expected $T$. Zaqueata of the Bonin Islands is similar to $T$. squamata and $T$. yesoensis because of its superficial resemblance of the form of body to the latter two species. Very interestingly, $T$. squamata and $T$. yesoensis are known to make the egg-sac in the form of a small and soft cotton ball hanging from the leaf by silken threads. My laboratory observation revealed, however, the egg-sac of $T$. Zaqueata is attached to the underside of a leaf (Fig. 3).

Body length of male, 5.2 to $6.6 \mathrm{~mm}$; female, 6.2 to $6.5 \mathrm{~mm}$.

This spider was observed or collected from the following localities on the Bonin Is. : Mt. Kuwanokiyama, Hahajima, (11. IV. 1973, Y. Kusui) ; Mt. Inokumadani, Hahajima, (1. I. 1975, T. Nagashima) ; Okimura, Hahajima, (5. III. 1975, T. Nagashima) ; Mt. Chūōzan-Mt. Yoakeyama, Chichijima, (20 and 25. I. 1980, C. Okuma) ; Mt. Kuwanokiyama, Hahajima, (22. I. 1980, C. Okuma) ; Mt. Chibusayama, Hahajima, (23. I. 1980, C. Okuma) ; Hyogidaira, Hahajima, (24. I. 1980, C. Okuma) ; Mt. Mikazukiyama, Chichijima, (27. I. 1980, C. Okuma) .

\section{References}

Berland, L., 1929, Araign., in: Insects of Samoa and other Samoan terrestrial Arthropoda. (London), $8(2): 35-78$.

Koch, L., 1871, Die A rachniden Australiens(Nürunberg),1: 1-248.

Marples, B. J., 1955, Spiders from Western Samoa, Journ.Zool. Linn. Soc. London, 42: 453504.

1957, Spiders from Some Pacific Islands II. Pacif. Sci. (Honolulu), 9: 386-395.

Simon, E., 1894, Histoire Naturelle des Araignées (Paris), 1(3) : 489-760.

Yaginuma, T., 1979, Spiders of the Bonin Islands, Japan. Nat. and Anim. (Japan), 9(8): 3336. 